\title{
Testicular Function of Actively Immunized Male Rats with LH Releasing Hormone (LHRH): A Possible Role of Prolactin on Regulation of Spermatogenesis
}

\author{
Kunio SHIOTA, Michio TAKAHASHI \\ AND YOSHISUKE SUZUKI \\ Department of Veterinary Physiology, Faculty of Agriculture, \\ University of Tokyo, Bunkyo-ku, Tokyo 113
}

\begin{abstract}
The effect of testosterone propionate (TP) on the recovery of spermatogenesis was compared in 3 types of experimentally induced gonadotropin-deficient rats ; 1 . hypophysectomized rats, 2 . rats actively immunized to LHRH and 3. hypophysectomized and immunized rats bearing a pituitary isograft. In order to immunize animals to LHRH, deamidated LHRH conjugated with BSA (LHRH-BSA) was injected intradermaly to male rats 4 times at 2 week intervals and additional booster injections continued once a month.

Anti-LHRH titer was the highest on the 12 th week and the titer remained at a relatively high levels thereafter. A remarkable decrease in testicular weight and testosterone production was achieved in 10 weeks associated with a drop in serum LH and FSH levels. In long term immunized rat (LIM rats) which had been immunized for more than 3 months, testicular atrophy advanced to a similar extent to that in long term hypophysectomized rats (HX rats).

The administration of TP ( $1 \mathrm{mg} /$ day) sc for 30 days restored spermatogenesis in LIM rats. The simultaneous administration of anti-LH and -FSH sera in addition to TP did not affect the restoration of spermatogenesis in LIM rats. The same TP treatment in HX rats, however, failed to restore spermatogenesis. Spermatogenesis was reinitiated after TP treatment if immunized-hypophysectomized rats received a pituitary isograft. Though the serum PRL level in LIM rats was one fifth of that in normal rats, a 2.5 -fold rise in the PRL level was observed after TP treatment.

These results suggest that PRL is involved in the process of spermatogenesis.
\end{abstract}

Hypophysectomy eliminates all hypophyseal hormones including, LH, FSH and prolactin (PRL) and impairment of spermatogenesis subsequently ensues. $\mathrm{LH}$ and

\footnotetext{
Received August 11, 1981.

Address requests for reprints to: Dr. Michio Takahashi, Laboratory of Veterinary Physiology, Faculty of Agriculture, University of Tokyo, 1-1-1 Yayoi Bunkyo-ku, Tokyo 113, Japan.

Present addresses: *Central Research Division, Takeda Chemical Industries, LTD., Yodogawa-ku, Osaka 532, Japan, and **Laboratory of Animal Physiology, Department of Agriculture, Meiji University, Ikuta-ku, Kawasaki 214, Japan.
}

FSH have a stimulatory effect on the restoration of spermatogenesis but spermatogeneisis is not fully restored by treatment with both hormones, suggesting the involvement of other hypophysial hormones in the regulation of spermatogenesis. The stimulatory effect of PRL was reported on the male reproductive function in rats (Hafiez et al., 1971, 1972a, b; Bartke et al., 1977; Negro-Vilar et al., 1977), seasonally breeding animals (Ravault, 1976), golden hamsters (Bex and Bartke, 1977; Bex et al., 1978; Bartke et al., 1980) and hereditary dwarf mice (Bartke and Lloyd, 
1970; Hafiez et al., 1971). The regulation of gonadal $\mathrm{LH}$ receptor by PRL was noted in male and female animals (Richards and Williams, 1976; Aragoma et al., 1977; Zipf et al., 1978; Morris and Saxena, 1980) and the mechanism of the gonad-stimulating action of PRL is considered to reside in the ability of PRL to increase number of LH receptors. However, the presence of other mechanisms of PRL action without mediating $\mathrm{LH}$ receptors were suggested (Crisp, 1977) and an inhibitory action of PRL on reproductive function was also reported (Fang et al., 1974; Winters and Lariaux, 1978). The significance of PRL in male animals is still debatable.

Hypophysectomized animals have been widely used in the study of hormonal control of spermatogenesis. As with hypophysectomy, the elimination of endogenous LHRH by active immunization against LHRH causes a deficiency of circulating LH and FSH (Makino et al., 1973; Fraser et al., 1974; Jeffcoat et al., 1976; Takahashi et al., 1978) and consequently lessened secretion of testicular androgen, and testicular androgen plays a primary role both in spermatogenesis and PRL secretion (Kalra et al., 1973; Shin et al., 1974; Ojeda et al., 1977).

Hypophysectomized and LHRH immunized rats, present differ in the ability to secrete hypophysial hormones other than LH and FSH (Jeffcoat et al., 1976; Takahashi et al., 1978). In this report testosterone propionate was chronically administered to androgen deficient rats prepared by hypophysectomy or immunization to LHRH and the restoration of spermatogenesis was compared to investigate the role of hypophysial hormones in the process of spermatogenesis.

\section{Materials and Methods}

\section{Animals}

Adult male Wistar rats bred in our laboratory were maintained on a commercial diet and tap water ad libitum under a light regimen of $14 \mathrm{~h}$ of light $(0500-1900 \mathrm{~h})$ and $10 \mathrm{~h}$ of darkness.

Immunization of rats with LHRH and collection of samples

Animals began to be immunized at 2 months old with LHRH conjugated with bovine serum albumin (BSA). The conjugate (LHRH-BSA) was prepared from $200 \mu \mathrm{g}$ deamidated LHRH from Dr. Fujino (Takeda Chemical Industries, Japan) by the carbodiimide method described before (Makino et $a l ., 1973$ ), dissolved in $0.3 \mathrm{ml}$ of $0.15 \mathrm{M} \mathrm{NaCl}$, emulsified with $0.3 \mathrm{~m} l$ Freund's complete adjuvant and injected intradermally into each animal at more than 10 sites on his dorsal skin. The first immunization was followed by 4 injections of the same amount of LHRH-BSA at weeks 2, 4, 6, and 10. Anti-LHRH titer and the serum LH, FSH and testostosterone levels were monitored at intervals throughout the experimental periods. Blood samples were collected by heart puncture under ether anesthesia. Testicular testosterone content, the weight of the testis and seminal vesicles were also determined using another group of animals subjected to the same schedule of immunization. A part of the testis samples harvested in week 12 was subjected to a histological study. They were fixed in a formalin solution and paraffin sections were stained with hematoxylin and eosin.

For the experiment using the long term immunized rats (LIM rats), the immunized rats received additional booster injections of the same amount of LHRH-BSA at 1-month intervals and were used between the 1 st and 4th booster injections. The weight of the thyroid and adrenal glands in LIM rats was compared with that of hypophysectomized rats operated 2 months before at 3 months old.

Serum PRL measurement in LIM and castrated rats after testosterone propionate (TP) or estradiol benzoate $(E B)$ administration

LIM and 5-month-old castrated rats operated 6 days before were injected sc with TP $(1 \mathrm{mg} / 0.1 \mathrm{~m} l$ sesame oil) or EB $(50 \mu \mathrm{g} / 0.1 \mathrm{~m} l$ sesame oil). The injections were repeated twice at 1600 and $1400 \mathrm{~h}$ the next day. An hour after the second injection, blood samples for PRL assay were collected by heart puncture under light ether anesthesia. 
Table 1. Protocol of Morphological Study for Spermatogenesis

\begin{tabular}{|c|c|c|c|c|c|c|}
\hline \multirow{2}{*}{$\begin{array}{l}\text { Abbreviation } \\
\text { \& Animal Condition }\end{array}$} & \multicolumn{3}{|c|}{ Treated } & \multicolumn{3}{|c|}{ Control } \\
\hline & Injection* & $\begin{array}{l}\text { Start of } \\
\text { Injection }\end{array}$ & $\begin{array}{l}\text { Collect. of } \\
\text { Testis }\end{array}$ & Injection* & $\begin{array}{l}\text { Start of } \\
\text { Injection }\end{array}$ & $\begin{array}{l}\text { Collect. of } \\
\text { Testis }\end{array}$ \\
\hline Intact & - & - & 5 month old & - & - & - \\
\hline \multirow[t]{4}{*}{$\begin{array}{l}\text { HX } \\
\text { (hypophysectomized) }\end{array}$} & TP $1 \mathrm{mg} /$ day & $\begin{array}{l}\text { immediately } \\
\text { after hypox }\end{array}$ & $\begin{array}{l}1 \text { day after } \\
\text { final inj. }\end{array}$ & - & - & - \\
\hline & & $\begin{array}{l}2 \text { weeks } \\
\text { after hypox }\end{array}$ & & - & - & $\begin{array}{l}2 \text { weeks } \\
\text { after hypox }\end{array}$ \\
\hline & & $\begin{array}{l}1 \text { month } \\
\text { after hypox }\end{array}$ & & & & $\begin{array}{l}1 \text { month } \\
\text { after hypox }\end{array}$ \\
\hline & & $\begin{array}{l}3 \text { months } \\
\text { after hypox }\end{array}$ & & & & $\begin{array}{l}3 \text { month } \\
\text { after hypox }\end{array}$ \\
\hline \multirow[t]{3}{*}{$\begin{array}{l}\text { LIM } \\
\text { (immunized) }\end{array}$} & TP $1 \mathrm{mg} /$ day & & $\begin{array}{l}1 \text { day after } \\
\text { final inj. }\end{array}$ & Sesame oil & & $\begin{array}{l}1 \text { day after } \\
\text { final inj. }\end{array}$ \\
\hline & $\begin{array}{l}\text { TP } 1 \mathrm{mg} / \mathrm{day}^{*} \\
+ \text { Anti-LH** }\end{array}$ & & & & - & - \\
\hline & $\begin{array}{l}\text { TP } 1 \mathrm{mg} l \text { day } \\
+ \text { Anti-FSH** }\end{array}$ & & & & & \\
\hline $\begin{array}{l}\text { LIMX } \\
\text { (immumized- } \\
\text { hypophysectomized) }\end{array}$ & TP $1 \mathrm{mg} /$ day & $\begin{array}{l}\text { immediately } \\
\text { after hypox }\end{array}$ & $\begin{array}{l}1 \text { day after } \\
\text { final inj. }\end{array}$ & - & - & - \\
\hline $\begin{array}{l}\text { LIMIX } \\
\text { (immunized- } \\
\text { hypophysectomized- } \\
\text { AP-grafted) }\end{array}$ & TP $1 \mathrm{mg} /$ day & $\begin{array}{l}\text { immediately } \\
\text { after hypox }\end{array}$ & $\begin{array}{l}1 \text { day after } \\
\text { final inj. }\end{array}$ & Sesame oil & $\begin{array}{l}\text { Immediately } \\
\text { after hypox } \\
\text { (1 week } \\
\text { after graft) }\end{array}$ & $\begin{array}{l}1 \text { day after } \\
\text { final inj. }\end{array}$ \\
\hline
\end{tabular}

* sc injection for 30 days. TP was dissolved in sesame oil $(1 \mathrm{mg} / 0.1 \mathrm{ml})$.

** Anti-LH serum, $0.4 \mathrm{ml} /$ day; Anti-FSH serum, $1.2 \mathrm{~m} l /$ day.

\section{Morphological study for spermatogenesis}

As listed in Table 1, intact, hypophysectomized (HX), immunized (LIM), immunized-hypophysectomized (LIMX) and immunized-hypophysectomizedpituitary-grafted (LIMIX) rats were subjected to morphological observation for spermatogenesis. Immunization for the LIM, LIMX and LIMIX groups, and hypophysectomy for the HX group were done at 2 months of age. TP was dissolved in sesame oil $(1 \mathrm{mg} / 0.1 \mathrm{~m} l)$ and injected sc once a day for 30 days. In HX rats, TP injection started either immediately after hypophysectomy, or 2 weeks, 1 month or 3 months later. The unilateral testis was removed before the injection as the control specimen. LIM rats received either sesame oil (control), TP, TP together with anti-LH serum $(0.4 \mathrm{~m} l /$ day $)$ or TP together with anti-FSH serum $(1.2 \mathrm{ml} /$ day $)$. Antiserum for LH or FSH was generated in rabbits by repeated injections of ovine LH (NIH-LH-S15) or porcine FSH (Armour Pharmaceutical Co.) emulsified with Freund's complete adjuvant, respectively. The amcunt of serum used in this study was proven to inhibit the occurrence of spontaneous ovulation in female rats if injected iv in the morning of proestrous for anti-LH or in the morning of metestrous for anti-FSH, respectively. LIM rats were hypophysectomized (LIMX) and received TP from the day of operation. The anterior pituitary removed from adult male rats was placed under the kidney capsule of the recipient-LIM rats anesthetized with ether. One week after the implantation, the in situ pituitary was removed (LIMIX) and TP injection was started. The vehicle was injected as a control. In HX, LIMX and LIMIX rats, hypophysectomy was performed by a parapharyngeal approach under ether anesthesia. The animals were autopsied at the end of the experiment to verify the complete removal of the pituitary gland.

One day after the final injection, animals were sacrificed and the testis was removed, weighed and fixed in Bouin's solution, and parafin sections were stained with hematoxylin and eosin.

\section{Measurement of anti-LHRH titer}

Binding activity of the antiserum to tritiated LHRH (New England Nuclear, Specific Activity; $30 \mathrm{Ci}$ / mmole) was maasured according to the method described previously (Takahashi et al., 1978). The titer was expressed as parcent binding at 1/100 dilution to $\left[{ }^{3} \mathrm{H}\right]-\mathrm{LHRH}$. The blank values in each assay about $10 \%$ were subtracted. 
Measurement of hormones

Duplicated aliquots of 50 to $200 \mu \mathrm{l}$ of sera were used for either LH, FSH or PRL. Samples were measured by each double antibody radioimmunoassay using the kits kindly donated by NIAMDD, according to the method described by Niswender et al. (1968) for LH and by Daane and Parlow (1971) for FSH or by Murakami et al. (1979) for PRL. Iodinated rat PRL (Specific Activity: $48.3 \mu \mathrm{Ci} / \mu \mathrm{g}$ ) was purchased from New England Nuclear. Each result was expressed in terms of NIAMDD-rat-LH-RP-1, NIAMDD-rat-FSH-RP-1 and NIAMDD-rat-PRL-RP1 , respectively. The assay sensitivity was $5 \mathrm{ng} / \mathrm{ml}$ for $\mathrm{LH}, 100 \mathrm{ng} / \mathrm{m} l$ for FSH or $2 \mathrm{ng} / \mathrm{m} l$ for PRL.

Testosterone was extracted from either peripheral serum or testicular homogenate with ethylether and measured by radioimmunoassay as described before (Shiota et al., 1976) using the antibody purchased from Dr. G. E. Abraham (S $741 \# 2$ ).

Statistical analysis was carried out by Student's $t$-test.

\section{Results}

(1) Changes in anti-LHRH titer and the organ weight

Fig. 1 shows the time course study of anti-LHRH titer and the organ weight during the course of immunization. A significant rise in the anti-LHRH titer was observed 2 weeks after the 1st injection of
LHRH-BSA $(p<0.05)$. The titer reached the maximum level at week 12 and a relatively high titer was maintained until week 18 without further injections of LHRH-BSA. Binding activity to $\left[{ }^{3} \mathrm{H}\right]-\mathrm{LHRH}$ was not observed in any sera taken from the control rats throughout the experimental period. On week 10, atrophy of the testis was detectable by palpation in all the immunized rats and testicular weight decreased to less than $300 \mathrm{mg}$. The testicular weight remained suppressed until week 18 . A weight decrease in the seminal vesicle was recognizable earlier than that in the testis.

Table 2 shows the weight of the adrenal and thyroidal glands in immunized rats later than week 10 of immunization (LIM rats) together with that in normal and hypophysectomized $\mathrm{HX}$ rats. Each body $(\mathrm{p}<0.01)$, adrenal $(\mathrm{p}<0.01)$ and thyroidal $(\mathrm{p}<0.05)$ weight was significantly lower in HX rats than the control, while a slight but significant increase in body and thyroidal weight $(\mathrm{p}<0.05)$ was observed in immunized rats. There was no significant difference between the adrenal weight in immunized and control rats.

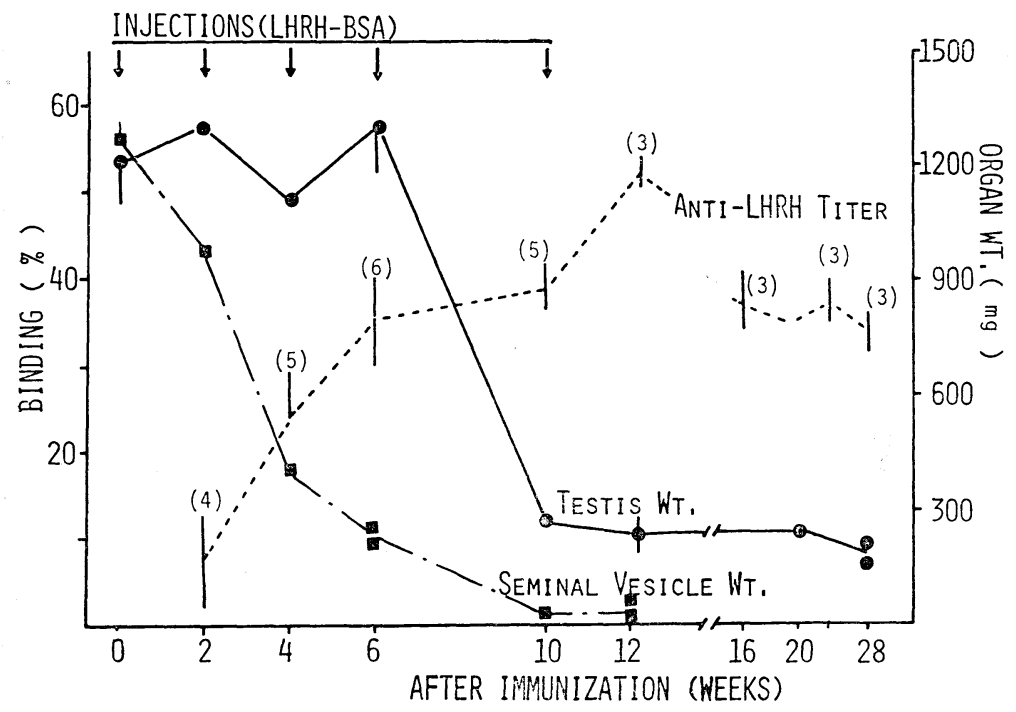

Fig. 1. Change in antiLHRH titer and organ weight during the course of immunization. The titer was expressed as percent binding of each serum at $1 / 100$ dilution to $\left[{ }^{3} \mathrm{H}\right]-\mathrm{LHRH}$. The number of animals is shown in parenthesis. Each vertical line represents S. E. of the mean. 
Table 2. Weight of boday, adrenal and thyroidal glands in long term immunized rats and hypophysectomized rats

\begin{tabular}{lccc}
\hline \hline & $\begin{array}{c}\text { Body wt. } \\
(\mathrm{g})\end{array}$ & $\begin{array}{c}\text { Adrenal wt. } \\
(\mathrm{mg})\end{array}$ & $\begin{array}{c}\text { Thyroid wt. } \\
(\mathrm{mg})\end{array}$ \\
\hline Intact control & $334.0 \pm 4.8^{*}$ & $46.0 \pm 3.2$ & $20.3 \pm 0.7$ \\
LHRH-Immunized & $394.8 \pm 22.2^{* *}$ & $41.4 \pm 3.4$ & $24.6 \pm 1.4^{* *}$ \\
Hypox (2 month) & $246.3 \bigcirc 11.0^{* * *}$ & $9.5 \bigcirc 1.2^{* * * *}$ & $15.7 \bigcirc 1.2^{* *}$ \\
\hline
\end{tabular}

* Mean $\bigcirc$ SEM. Five rats were used for each group.

$* * \mathrm{p}<0.05 \mathrm{vs}$. control

$* * * \mathrm{p}<0.01$ vs. control

(2) Testosterone concentration in peripheral and testicular tissue in immunized rats.

The testosterone concentration in peripheral blood during the course of immunization was measured and correlated with the antibody titer individually (Fig. 2). There was a distinct negative correlation between the two parameters. Testosterone content of the testis in immunized and control rats is shown in Fig. 3. In testes collected at weeks 4 and 6 in immunized rats, testosterone decreased to a much lower level than that in control rats though testicular weight (around 1,000 mg) still remained at $76.3 \%$ of the control. Testicular testosterone levels decreased further and then a marked reduction took place in the testicular weight in week 10 .

(3) Serum LH and FSH levels in immunized rats.

The serum LH and FSH levels tended to continue to decrease during the course of immunization, though a wide range of variations was associated with the $\mathrm{LH}$ value (Fig. 4). A slight elevation in $\mathrm{LH}$ in week 2 was not significant $(p>0.05)$. Sera collected at weeks 4,6 and 10 showed significantly lower LH levels than those collected at Week $2(\mathrm{p}<0.05)$.
(4) Serum PRL level in LIM, castrated and normal rats before and after TP or EB treatment.

The serum PRL concentration in intact, castrated or LIM rats is shown in Table 3. The PRL level in castrated and LIM rats was significantly lower $(\mathrm{p}<0.05)$ than that in normal rats. The PRL concentration in LIM rats remained at about a half of that in normal rats. The treatment with TP or EB resulted in 2.5- and 4.5-fold increase in LIM and castrated rats, respectively.

(5) Effects of TP treatment on spermatogenesis of LIM and hypophysectomized rats under various hormonal milieu.

As shown in Plate 1, the involution of seminiferous tubules and Lydig cells was evident in immunized rats on week 12 (Fig. 6) and hypophysectomized rats (Figs. 7-9). Degeneration proceeded in the testis of hypophysectomized rats with the lapse of time after the operation.

Testicular specimens from LIM and hypophysectomized rats treated with TP are presented in Plate 2. In hypophysectomized rats, TP treatment failed to restore spermatogenesis (Figs. 12-14), while in LIM rats the restoration was significant and mature spermatozoa were found in the lumen (Fig. 11). Vehicle treatment to LIM rats had no effect on spermatogenesis (Fig. 10). Simultaneous administration of anti- 


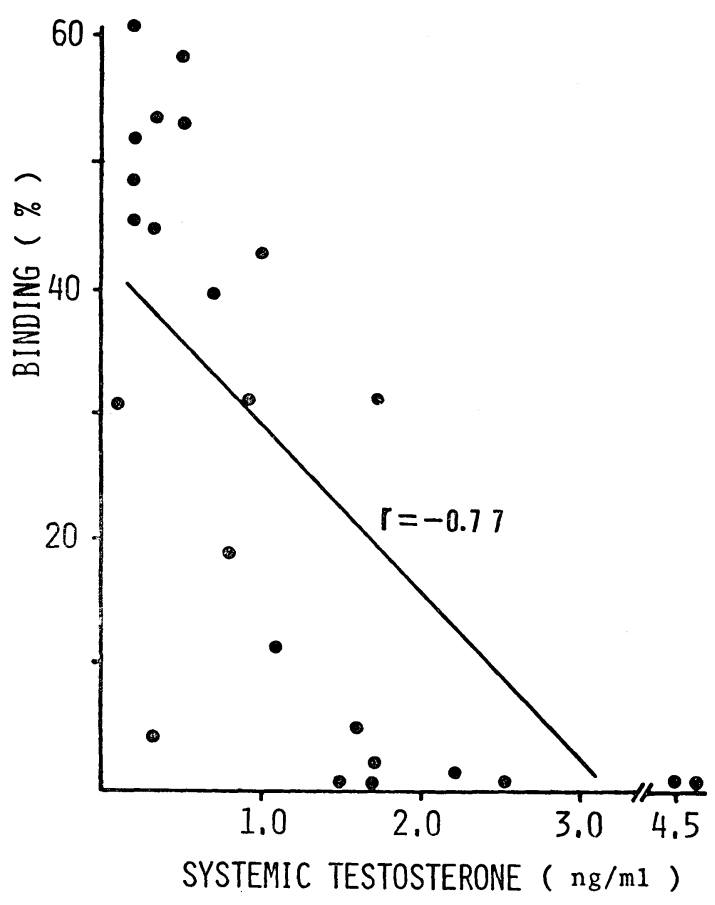

Fig. 2. Correlation between anti-LHRH titer and serum testosterone concentration. Blood samples were collected during the course of immunization until week 28.

LH or -FSH serum did not affect the restoration of spermatogenesis in TP-treated LIM rats (Plate 3, Figs. 15 and 16).

When LIM rats were hypophysectomized (LIMX rats) before TP treatment, spermatogenesis was not restored (Plate 4, Fig. 17). In LIMX rats which were previously transplanted with the anterior pituitary ectopically under the kidney capsule (LIMIX rats), however, TP treatment again was effective in reinitiating spermatogenesis (Plate 4, Fig. 19). Without TP treatment, a slight increase in tubule diameter was observed in LIMIX rats Plate 4, Fig. 18) compared with LIM rats Plate 2, Fig. 12).
(6) Testicular weight in LIM and hypophysectomized rats after TP treatment.

Fig. 20 shows the testicular weight in various groups mentioned above at the end of experimental manipulation. TP treatment failed to increase the testicular weight in 2-week-hypophysectomized rats and slightly increased it in 1 - or 3-monthhypophysectomized rats. If the treatment started on the day of hypophysectomy, the testicular weight remained at the normal level. In contrast, TP treatment resulted in a significant testicular weight gain $(\mathrm{p}<0.05)$ in immunized rats so long as the anterior pituitary was kept either in situ or ectopically.

\section{Discussion}

The present study confirms previous observations (Fraser et al., 1974; Jeffcoat et al., 1976; Takahashi et al., 1978) that immunoneutralization of exogenous LHRH resulted in a decrease in the secretion of LH and FSH. The deficiency of $\mathrm{LH}$ and FSH in our preparation lasted for a long period after the final treatment with LHRHBSA. Serum FSH concentrations continued to decrease in an inverse relationship with the LHRH-titer, whereas those of LH showed 2 rises at weeks 2 and 6 of immunization, though they were not statistically significant. This apparent difference could partly be attributed to the difference in the magnitude of the discharge in the release of each hormone (Desjardins, 1981). LH pulses of greater magnitude than those of FSH may be evaluated as higher variability of mean values in the infrequent sampling schedule employed in this study.

The weight of the seminal vesicle decreased to a minimal level at week 6 to 10 of immunization. In contrast to a fast and steady decrease in the weight of the seminal vesicle in immunized animals, that 


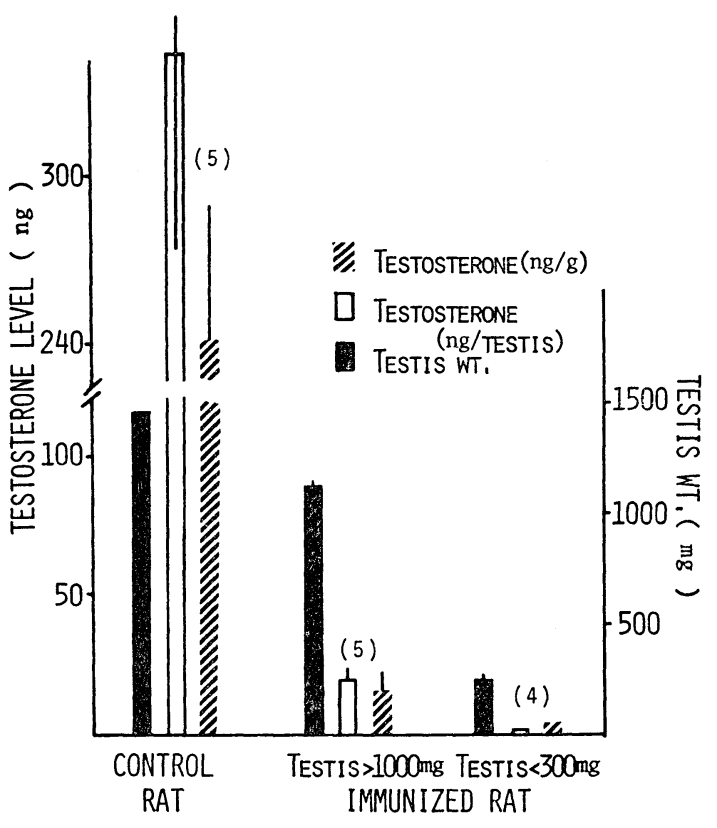

Fig. 3. Testosterone content in testicular tissue and weight of the testis in immunized and control rats. In immunized rats, testes were classified into 2 groups according to weight. The testes collected at weeks 4 and 6 were heavier than $1000 \mathrm{mg}$ and those collected at weeks 10 and 12 were less than $300 \mathrm{mg}$. The number of animals is shown in parenthesis. Each vertical line represents S.E. of the mean.

in the testis was much slower; the testicular weight at week 6 to 10 still remained at $76 \%$ of control. Serum FSH during the same experimental period was at $50 \%$ of the control level and a marked reduction in testicular weight was associated with a decrease in serum FSH to less than 25\% of the control level. Thus, the slow decrease of tesiticular weight seemed mostly due to the decrease in the serum FSH concentration during the course of immunization. It is suggested that the secretion of FSH resists the reduction of LHRH stimuli in comparison to that of LH (Knobil, 1981).
In LIM rats which continued to receive monthly injections of LHRH-BSA since week 10, serum PRL concentrations were significantly lowered. This is in accord with previous reports (Fraser, 1976; Takahashi et al., 1978) showing that active immunization with LHRH results in the lowering of serum PRL levels in female or male rats. There have been reports (Kalra et al., 1973; Shin et al., 1974 ; Ojeda et al., 1977) indicating that castration lowers the PRL concentration in the pituitary and peripheral blood and that these decreases are prevented by the administration of estradiol or testosterone. In the present experiment, serum PRL level was elevated by TP or EB treatment in LIM rats as in orchidectomized animals, suggesting that lowered PRL levels in LIM rats were caused by a reduced outflow of testicular steroids. Since the testis secretes estrogen under FSH control (Dorrington et al., 1978), the decrease in the serum PRL concentration in LIM rats is considered to be caused by a deficiency of FSH as well as LH. The serum PRL level in LIM rats was significantly lower than in the rats orchidectomized 6 days before, and may result from the longer steroid-deficient period than that in castrated rats.

Impairment of spermatogenesis, involution of the seminiferous tubule and atrophy of Leydig cells in LIM rats occurred to the same extent as in long term (for 3 months) hypophysectomized (HX) rats. Administration of $\mathrm{TP}$ for 30 days reinitiated spermatogenesis and increased testicular weight in LIM rats. When LIM rats were hypophysectomized before the start of TP treatment, however, the treatment could induce neither spermatogenesis nor testicular weight gain. The serum FSH concentration was still above the nondetectable level on week 10 of immunization. Synergistic action of FSH and androgen on the restoration of spermatogenesis is known (Steinberger, 1971). To minimize the possibility that the minute 
Fig. 4. Serum LH and FSH concentrations during the course of immunization. The results were expressed in term of NIAMDDrat-LH-RP-1 and NIAM DD-FSH-RP-1. The number of animals is shown in parenthesis. Each vertical line represents S. E. of the mean.

Table 3. Prolactin concentration after treatment of TP or EB in long term immunized and castrated rats

\begin{tabular}{|c|c|c|}
\hline & \multicolumn{2}{|c|}{$\begin{array}{c}\text { Prolactin Conc. } \% \text { Increase Ratio } \\
(\mathrm{ng} / \mathrm{m} l \text { serum })\end{array}$} \\
\hline Intact $(5)^{*}$ & $8.48 \times 0.70$ & - \\
\hline $\begin{array}{l}\text { Castrated (5) } \\
\text { (Control) }\end{array}$ & $3.09 \times 0.29^{* *}$ & - \\
\hline $\begin{array}{l}\text { Castrated (5) } \\
\quad+\mathrm{TP}\end{array}$ & $7.31 \times 1.70^{* * *}$ & 2.36 \\
\hline $\begin{array}{l}\text { Castrated (5) } \\
\quad+\mathrm{EB} \\
\end{array}$ & $13.48 \times 1.49^{* * *}$ & 4.36 \\
\hline LIM (control) (4) & $1.70 \times 0.41$ & - \\
\hline LIM TP & $4.53 \times 0.40^{* * *}$ & 2.67 \\
\hline $\mathrm{LIM}+\mathrm{EB}$ & $8.34 \times 1.35 * * *$ & 4.91 \\
\hline
\end{tabular}

LIM and castrated rats were injected sc with TP $(1 \mathrm{mg})$ or EB $(50 \mathrm{ug})$. The injections were repeated twice at 1600 and $1400 \mathrm{hr}$ the next day. An hour after the second injection, blood samples were collected.

\footnotetext{
* Number of rats

$* *$ Mean $\times$ SEM

$* * * \mathrm{p}<0.05$ vs. control

※ NIAMMD-rat-PRL-RP-1
}

amount of LH and FSH secreted in LIM rats, if any, might still be effective on those restoring events, anti-LH or -FSH serum was administered simultaneously with TP. The extent of the restration was not altered by both anti-hormone injections. The hypophysial hormones other than LH and FSH, therefore, seemed to contribute to the restration of spermatogenesis in TP-treated LIM rats.

In immunized-hypophysectomized rats once transplanted with the anterior pituitary ectopically, recovery of spermatogenesis and testicular weight gain became evident by TP treatment. The pituitary graft under the kidney capsule has been used for the continuous and selective supply for PRL, though associating secretion of slight amount of $\mathrm{LH}, \mathrm{FSH}$ and growth hormone were reported (Hjalmarson and Ahren, 1965 ; Lam et al., 1976). The secretion of gonadotropins from the grafted pituitary is considered to depend on circulating LHRH (Evans and Nikitovitch-Winer, 1969 ; Arimura et al., 1973) but LHRH in the immunized rats was continuously neutralized 


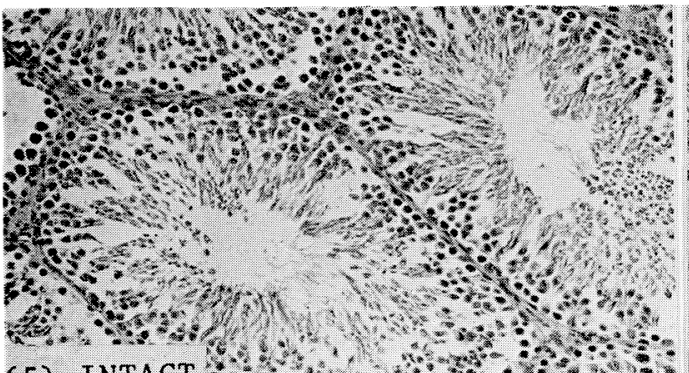

(5) INTACT

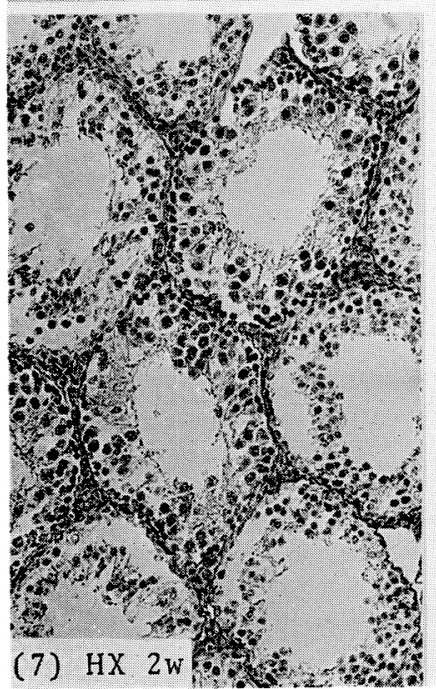

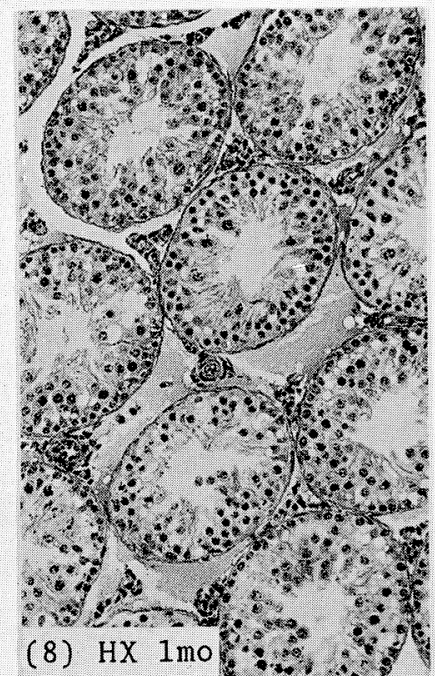

(5) IMMUNIZED
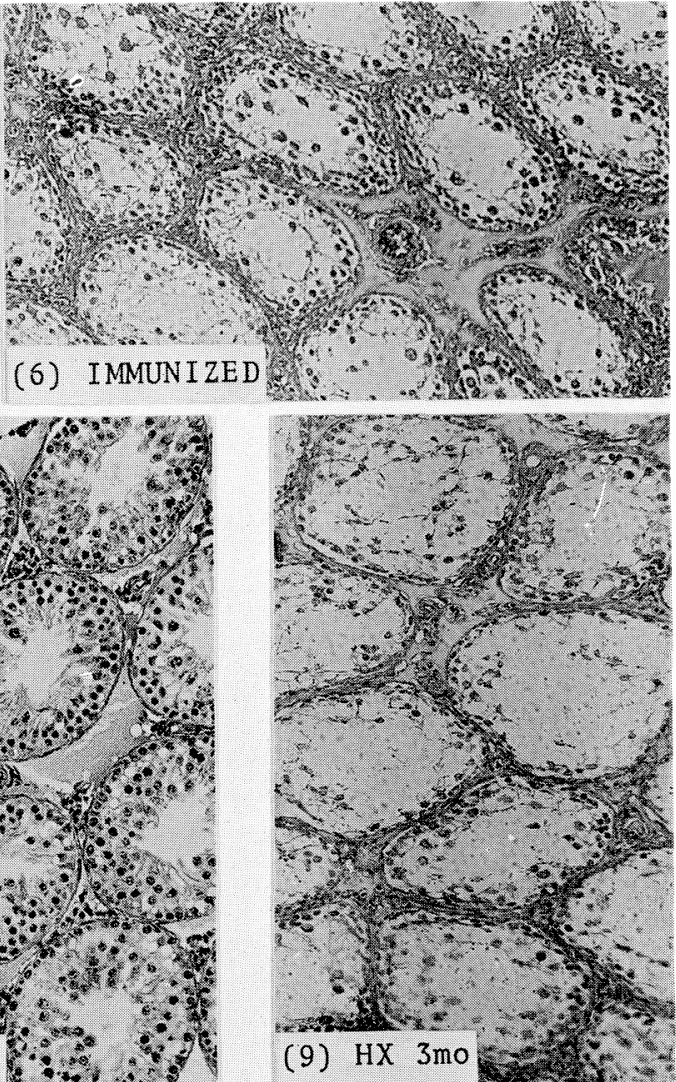

Plate 1. Comparism of testicular morphology in intact, immunized and hypophysectomized rats. Fig. 5, intact 5 month old rats; Fig. 6, immunized rat testis at week 12; Fig. 7-9, Hypophysectomized rat testis, which was collected 2 weeks (HX $2 \mathrm{w}$ ), 1 month (HX 1 mo) or 3 months (HX 3 mo) after hypophysectomy.

in the circulation. Therefore, the synthesis and the release of LH and FSH from the grafted pituitary in LIM rats should be minimized. Thus, the most probable candidate that stimulated spermatogenesis in LIM rats in the presence of testosterone was PRL.

A possible involvement of pituitary hormones other than LH and FSH has been widely accepted in the regulation of testicular fuction. Among them, the presence of the specific receptor for PRL (Aragona and Friesen, 1975; Aragona et al., 1977) and the regulation of $\mathrm{LH}$ receptor by PRL in the testis were reported (Zipf et al., 1978; Morris and Saxena, 1980). PRL stimulation of $3 \beta$-hydroxysteroid dehydrogenase activity (Hafiez et al., 1971), incorporation of acetate to testosterone (Hafiez et al., 1972a) and testosterone production (Hafiez et al., 1972b) were demonstrated using hypophysectomized LH-treated rats. In contrast, the inhibition of testicular function in hyperprolactinemic condition 


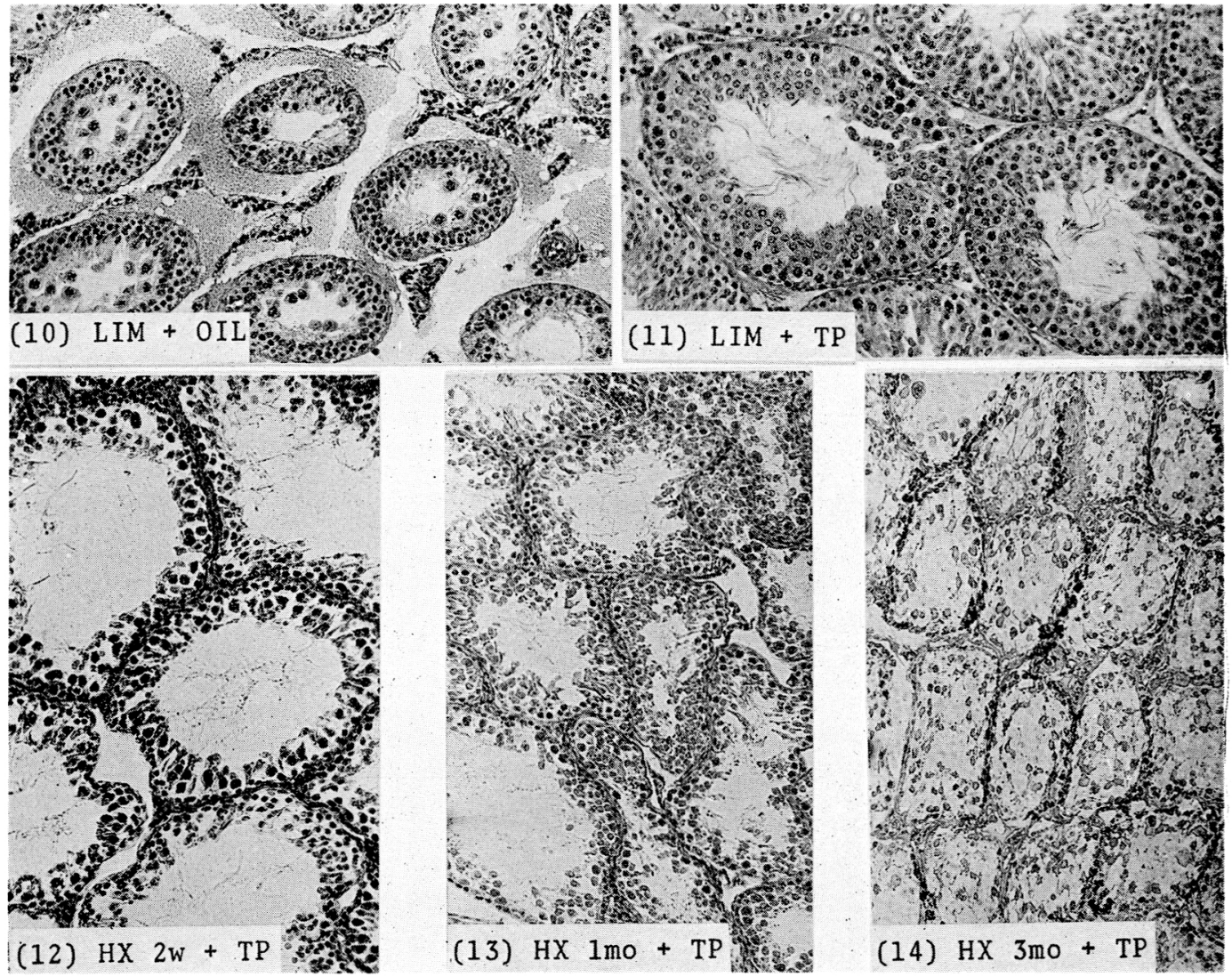

Plate 2. Effect af TP treatment $(1 \mathrm{mg}$ in $0.1 \mathrm{ml}$ sesame oil/day $\mathrm{sc}$ for 30 days) on the recovery of spermatogenesis in LIM and hypophysectomized rats. Fig. 10, LIM vehicle control. LIM rats received sc $0.1 \mathrm{ml}$ of sesame oil (LIM+oil); Fig. 11, LIM rats received TP (LIM+TP); Figs. 12-14, TP injection was initiated 2 weeks (HX $2 \mathrm{w}+\mathrm{TP}), 1$ month (HX 1 mo+TP) or 3 months (HX 3 mo $+\mathrm{TP})$ after hypophysectomy. The testes were collected one day after the final injection.

was reported (Fang et al., 1974; McNeilly et al., 1978; Winters and Loriaux, 1978), but this inhibition might be mostly due to an aberration of gonadotropin secretion. PRL was also reported to stimulate spermatogenesis in LH-treated hypophysectomized rats (Wood and Simpson, 1961; Boccabells, 1963) in hereditary dwarf mice (Bartke and Lloyd, 1970) and in hypophysectomized mice (Bartke, 1971). Though these authors claimed that the spermatogenic action of PRL was effected via augumentation of $\mathrm{LH}$ action rather than potentiation of androgen action on spermatogenesis, it seems plausible that TP treatment alone is unable to restore spermatogenesis in long term hypophysectomized animals from the present study and others (Woods and Simpson, 1961). Success in the recovery of spermatogenesis in LIM rats with only TP treatment, thus, strongly suggests that PRL has a permissive role in the completion and maintenance of spermatogenesis by androgen. Further studies to elucidate this permissive action in detail are in progress. 

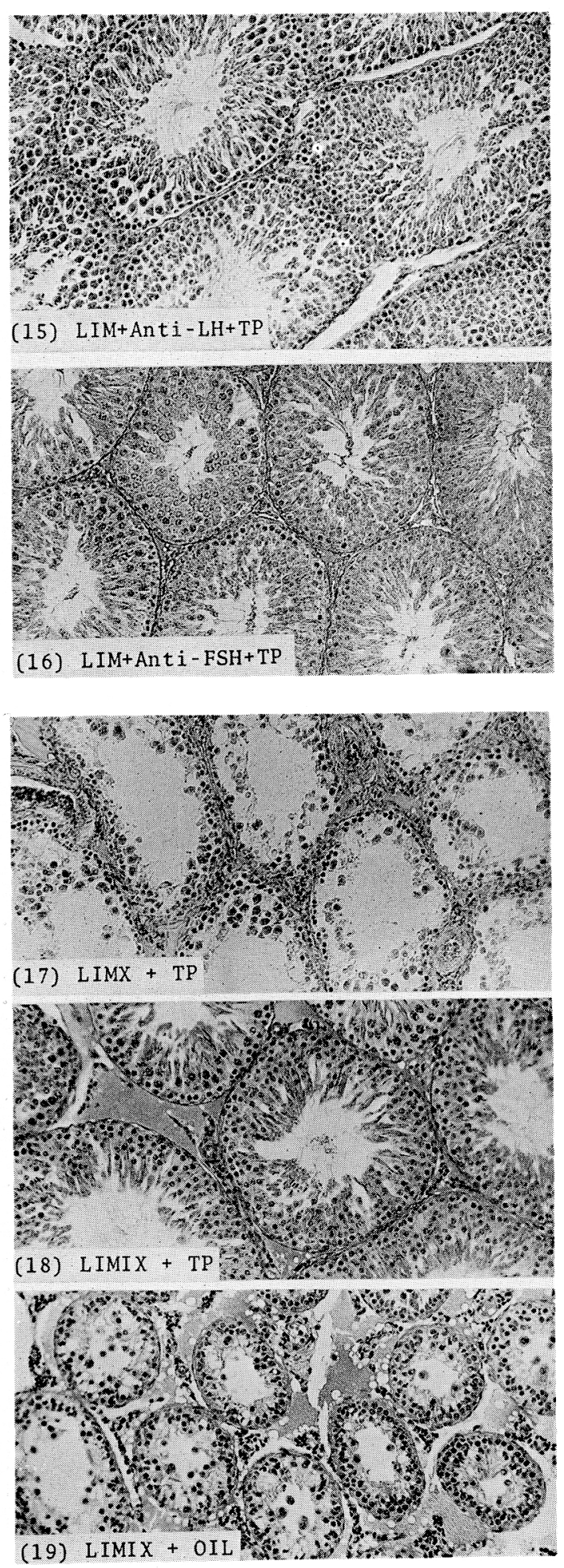

Plate 3. Effects of TP injection (1 mg in $0.1 \mathrm{~m} !$ sesame oil/day sc for 30 days) together with anti-LH serum $(0.4 \mathrm{~m} l /$ day, Fig. 15$)$ or anti-FSH serum $(1.2 \mathrm{ml} /$ day, Fig. 16) on the recovery of spermatogenesis. The testes were collected one day after the final injection.
Plate 4. Effects of TP injection ( $1 \mathrm{mg}$ in $0.1 \mathrm{ml}$ sesame oil/day sc for 30 days) on the recovery of spermatogenesis in immunized-hypophysectomized and immunized-hypophysectomized-pituitary isografted rats. Fig. 17, LIM rats were hypophysectomized befor TP treatment (LIMX+ TP); Figs. 18 and 19, LIM rats were transplanted with the anterior pituitary under the kidney capsule and the in situ pituitary was removed before the injection of TP (IMIX + TP) or sesame oil (LIMIX+oil). The testes were collected one day after the final injection. 


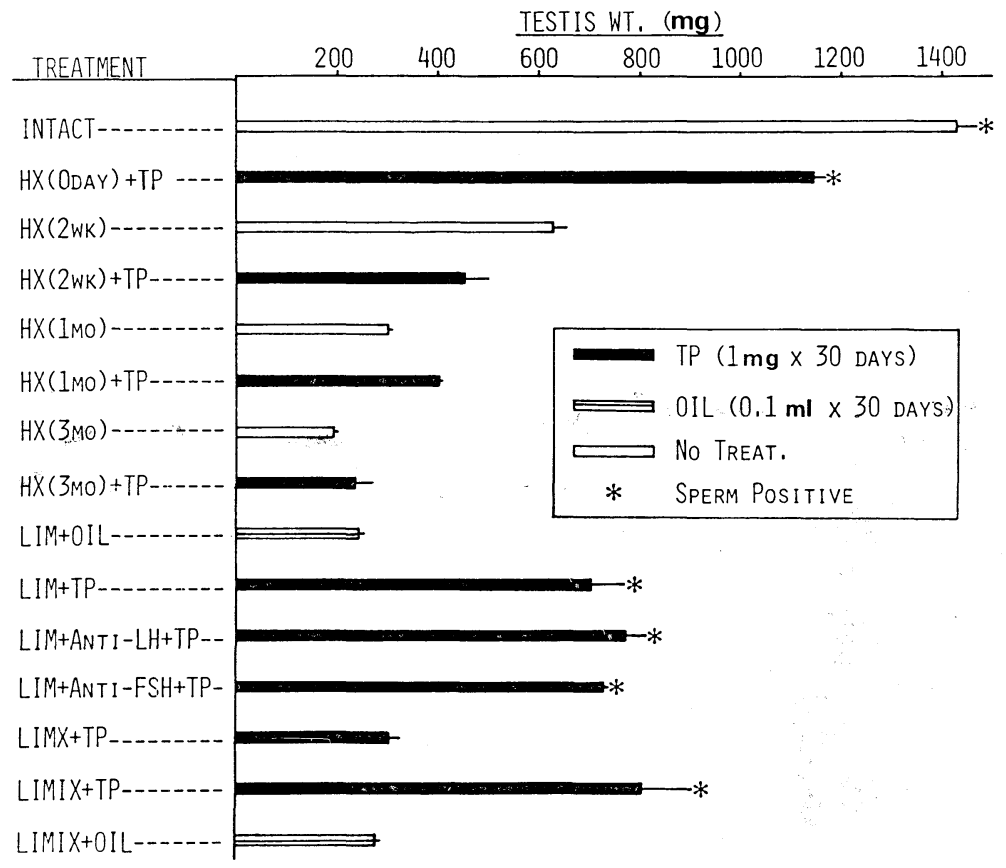

Fig. 20. Testicular weight in immunized (LIM), hypophysectomized (HX) immunized-hypophysectomized (LIMX), immunized-hypophysectomizedpituitary grafted (LIMIX) rats after TP treatment ( $1 \mathrm{mg} /$ day sc fcr 30 days).

\section{Acknowledgements}

The authors are thankful to the NIAMDD, NIH, for supplying materials for the radioimmunoassay, The authors are also grateful to Dr. Masahiko Fujino (Takeda Chem. Ind. Ltd.) for supplying deamidated LHRH, Dr. Hiroyoshi Horikoshi (Sankyo Co. Ltd.) for his valuable advice and Mrs. Toshiko Nomoto for her help in preparing the manuscript.

\section{References}

Aragona, C. and H. G. Friesen (1975). Specific prolactin binding sites in the prostate and testis. Endocrinology 97, 677-684.

Aragona, C., H. G. Bohnet and H. G. Friesen (1977). Localization of prolactin binding in prostate and testis: The role of serum prolactin concentration on the testicular LH receptor. Acta Endocrinol. (Kbh.) 84, 402-409.

Arimura, A., L. Debeljuk, M. Shiino, E. G. Rennels and A. V. Schally (1973). Follicular stimulation by chronic treatment with synthetic LHreleasing hormone in hypophysectomized female rats bearing pituitary grafts. Endocrinology 92, 1507-1514.

Bartke, A. and C. W. Lloyd (1970). Influence of prolactin and pituitary isografts on spermatogenesis in dwarf mice and hypophysectomized rats. J. Endocrinol. 46, 321-329.

Bartke, A. (1971). Effects of prolactin on spermatogenesis in hypophysectomized mice. J. Endocrinol. 49, 311-316.

Bartke, A., B. D. Goldman, F. J. Bex, R. P. Kelch, S. Dalterio, P. C. Doherty and M. S. Smith (1980). Effects of prolactin on testicular regression and recrudescence in the golden hamster. Endocrinology 106, 167-172.

Bartke, A., M. S. Smith, S. D. Michael, F. G. Peron and S. Dalterio (1977). Effects of experimentallyinduced chronic hyperprolactinemia on testosterone and gonadotropin levels in male rats and mice. Endocrinology 100, 182-186.

Bex, F. J. and A. Bartke (1977). Testicular LH binding in the hamster: Modification by photoperiod and prolactin. Endocrinology 100, 1223-1226.

Bex, F., A. Bartke, B. D. Goldman and S. Dalterio (1978). Prolactin, growth hormone, luteinizing hormone receptors, and seasonal changes in testicular activity in the golden hamster. Endocrinology 103, 2069-2080.

Boccabella, A. V. (1963). Reinitiation and restoration of spermatogenesis with testosterone propionate and other hormones after a long-term posthypophysectomy regression period. Endocrinology 72, 787-798. 
Crisp, T. M. (1977). Hormone requirements for early maintenance of rat granulosa cell cultures. Endocrinology 101, 1286-1297.

Daane, T. A. and A. F. Parlow (1971). Periovulatory patterns of rat serum follicle stimulating hormone and luteinizing hormone during the normal estrous cycle: Effects of pentobarbital. Endocrinology 88, 653-663.

Desjardins, C. (1981). Endocrine signaling and male reproduction. Biol. Reprod. 24, 1-21.

Dorrington, J. H., I. B. Fritz and D. T. Armstrong (1978). Control of testicular estrogen synthesis. Biol. Reprod. 18, 55-64.

Evans, J. S. and M. B. Nikitovitch-Winer (1969). Functional reactivation and cytological restoration of pituitary grafts by continuous local intravascular infusion of median eminence extracts. Neuroendocrinology 4, 83-100.

Fang, V. S., S. Refetoff and R. L. Rosenfield (1974). Hypogonadism induced by a transplantable, prolactin-producing tumor in male rats: Hormonal and morphological studies. Endocrinology 95, 991998.

Fraser, H. M. (1976). Physiological effects of antibody to luteinsing hormone realeasing hormone. In: Clinical and Experimental Immunoreproduction 3 "Physiological Effects of Immunity against Reproductive Hormones"' (R. G. Edwards and M. H. Johnson ed.), Cambridge University Press. pp. 137-165.

Fraser, H. M., A. Gunn, S. L. Jeffcoate and D. T. Holland (1947). Effect of active immunization to luteinizing hormone releasing hormone on serum and pituitary gonadotrophins, testes and accessory sex organs in the male rat. J. Endocrinol. 63, 399-406.

Hafiez, A. A., A. Bartke and C. W. Lloyd (1972a). The role of prolactin in the regulation of testis function: The synergistic effects of prolactin and luteinizing hormone on the incorporation of $1-{ }^{14} \mathrm{C}$ acetate into testosterone and cholesterol by testes from hypophysectomized rats in vitro. J. Endocrinol. 53, 223-230.

Hafiez, A. A., C. W. Lloyd and A. Bartke (1972b). The role of prolactin in the regulation of testis function: The effects of prolactin and luteinizing hormone on the plasma levels of testosterone and androstenedione in hypophysectomized rats. $J$. Endocrinol. 52, 327-332.

Hafiez, A. A., J. E. Philpott and A. Bartke (1971). The role of prolactin in the regulation of testicular function: The effect of prolactin and luteinizing hormone on $3 \beta$-hydroxysteroid dehydrogenase activity in the testes of mice and rats. $J$. Endocrinol. 50, 619-623.

Hjalmarson, A. and K. Ahrén (1965). Studies on growth hormone secretion in rats with the hypophysis autotransplanted to the kidney capsule. Acta Endocrinol. (Kbh.) 49, 17-27.
Jeffcoate, S, L., D. T. Holland and H. M. Fraser (1976). Anti-LH-RH sera in the investigation of reproduction. In: Clinical and Experimental Immunoreproduction 3 "Physiological Effects of Immunity against Reproductive Hormones" (R. G. Edwards and M. H. Johnson ed.), Cambridge University Press. pp. 121-136.

Kalra, P. S., C. P. Fawcett, L. Krulich and S. M. McCann (1973). The effects of gonadal steroids on plasma gonadotropins and prolactin in the rat. Endocrinology 92, 1256-1268.

Knobil, E. (1981). Patterns of hypophyseotropic signals and gonadotropin secretion in the rhesus monkey. Biol. Reprod. 24, 44-49.

Lam, P. C. O., W. K. Morishige and I. Rothchild (1976). Venous outflow of the hormones secreted by the rat pituitary autotransplanted beneath the kidney capsule. Proc. Soc. Exp. Biol. Med. 152, 615-617.

Makino, T., M. Takahashi, K. Yoshinaga and R. O. Greep (1973). Ovulation blockade in rats by rabbit anti-luteinizing hormone releasing factor serum. Contraception 8, 133-145.

McNeilly, A. S., R. M. Sharpe, D. W. Davidson and H. M. Fraser (1978). Inhibition of gonadotrophin secretion by induced hyperprolactinaemia in the male rat. J. Endocrinol. 79, 59-68.

Morris, P. L. and B. B. Saxena (1980). Dose- and age-dependent effects of prolactin (PRL) on luteinizing hormone- and PRL-binding sites in rat Leydig cell homogenates. Endocrinology 107, 16391645 .

Murakami, N., M. Takahashi and Y. Suzuki (1979). Indispensable role of peripheral progesterone level for the occurrence of prolactin surges in psudopregnant rats. Biol. Reprod. 21, 263-268.

Negro-Vilar, A., W. A. Saad and S. M. McCann (1977). Evidence for a role of prolactin in prostate and seminal vesicle growth in immature male rats. Endocrinology 100, 729-737.

Niswender, G. D., A. R. Midgley, Jr., S. E. Monroe and L. E. Reichert, Jr. (1968). Radioimmunoassay for rat luteinizing hormone with antiovine LH serum and ovine LH-131I. Proc. Soc. Exp. Biol. Med. 128, 807-811.

Ojeda, S. R., A. Castro-Vázquez and H. E. Jameson (1977). Prolactin release in response to blockade of dopaminergic receptors and to TRH injection in developing and adult rats: Role of estrogen in determining sex differences. Endocrinology 100, 427-439.

Ravault, J. P. (1976). Prolactin in the ram: Seasonal variations in the concentration of blood plasma from birth until three years old. Acta Endocrinol. (Kbh.) 83, 720-725.

Richards, J. S. and J. J. Williams (1976). Luteal cell receptor content for prolactin (PRL) and luteinizing hormone (LH): Regulation by LH and PRL. Endocrinology 99, 1571-1581. 
Shin, S. H., R. B. Aiken, R. Roberts and C. Howitt (1974). Effect of testosterone on serum prolactin in the castrated rat. J. Endocrinol. 63, 257-258.

Shiota, K., M. Takahashi and Y. Suzuki (1976). Intratesticular tissue fluid (ITF) for the microbioassay of LH. Endocrinol. Japon. 23, 143-147.

Steinberger, E. (1971). Hormonal control of mammalian spermatogenesis. Phys. Rev. 51, 1.

Takahashi, M., J. J. Ford, K. Yoshinaga and R. O. Greep (1978). Active immunization of female rats with luteinizing hormone releasing hormone
(LHRH). Biol. Reprod. 17, 754-761.

Winters, S. J. and D. L. Loriaux (1978). Suppression of plasma luteinizing hormone by prolactin in the male rat. Endocrinology 102, 864-868.

Woods, M. C. and M. E. Simpson (1961). Pituitary control of the testis of the hypophysectomized rat. Endocrinology 69, 91-125.

Zipf, W. B., A. H. Payne and R. P. Kelch (1978). Prolactin, growth hormone, and luteinizing hormone in the maintenance of testicular luteinizing hormone receptors. Endocrinology 103, 595-600. 